\title{
The Impact of the Regent of Gianyar's Circular Letter No. 400/0793/Setda/2020 on Income and Welfare Levels of Mses in the Gianyar Regency
}

Wayan Firstia Arika Savitri ${ }^{1}$ Putu Diah Pradnya Paramitha ${ }^{1, *}$ Putu Eka Kusumayani ${ }^{2}$

Komang Ade Komala Savitri ${ }^{1}$ Ni Luh Rani Damayanti ${ }^{1}$ Ni Ketut Sri Budayani ${ }^{1}$

\begin{abstract}
${ }^{1}$ Department of Economic and Accounting Universitas Pendidikan Ganesha, Singaraja, Indonesia
${ }^{2}$ Department of Economic and Accounting Universitas Pendidikan Ganesha, Singaraja, Indonesia

${ }^{*}$ Corresponding author. Email: diah.pradnya@undiksha.ac.id
\end{abstract}

\begin{abstract}
COVID-19 pandemic causes a change of management system in society. Every society level needs to make several adjustments in their social activities which are also supported by the government. One of the forms of government support is publishing new regulations to prevent the spread of COVID-19. This study figured out the impact of circular issued by the Regent of Gianyar No: 400/0793 / Setda / 2020, which was about the procedures for preventing the spread of COVID-19 in public markets, senggol markets, and supermarkets to the income and welfare of micro and small businesses in Gianyar Regency. This research used quantitative descriptive approach. This approach was chosen to describe the impact of the circular issuance. The population in this study were all middle and upper enterprises in Gianyar Regency. Meanwhile, the sample were 381 respondents who were determined by Slovin formula. Questionnaire and interview were employed as the data collection method. Furthermore, descriptive analysis was used as the data analysis technique. The result of the study shows that the circular gives impact to the income descent and welfare level descent of the middle and upper enterprises in Gianyar Regency.
\end{abstract}

Keywords: Government document, Income and welfare, MSEs.

\section{INTRODUCTION}

Corona Virus Disease 2019 (COVID-19) originally emerged in China in December 2019, and has since spread to nearly every country on the planet. COVID-19 is a virus that can infect people and causing coughs, colds, and other respiratory diseases, according to the World Health Organization. Furthermore, no one knows how to deal with this type of infection, generating concern in a number of countries [1].

China, Italy, the United States, and Spain have all been affected by the pandemic, prompting the International Monetary Fund (IMF) to forecast a slowing of global economic growth, which is already negative 3\% [2]. This pandemic is spreading quickly in Indonesia, infecting thousands of Indonesian citizens in a short period of time, so the government is taking precautionary measures to prevent the spread of COVID-19 by tightening the implementation of health protocols throughout Indonesia while being guided by the central government (Disantara). The issue of Presidential Decree No. 11 of 2020 of the Republic of Indonesia about the determination of a public health emergency of corona virus disease 2019 facilitates this preventive measure (COVID-19). The COVID-19 disease is defined in this judgment as a disease that produces a public health emergency that must be managed in line with the law's provisions. Government Regulation No. 21 of 2020 Concerning Large-Scale Social Restrictions (PSBB) was issued by the president.

The introduction of this regulation has a positive influence on keeping the COVID-19 virus from spreading, but it has a negative impact on the Indonesian economy [3] The trade, tourism, and investment sectors are all suffering as a result of the pandemic. According to the Indonesian Institute of Sciences' study and simulations, the country's predicted economic growth is only 1.9 percent to 2.2 percent [4] [4] Meanwhile, according to BPS statistics, Indonesia's economic growth in the first quarter was just 2.97 
percent, a significant drop from the previous quarter's 5.97 percent, and minus 5.32 percent in the second quarter [5].

The basic economic sector, notably the micro and small business sector (UMK), which is a business sector that is very connected to the community, is undoubtedly impacted by the epidemic [6] According to data from the 2019 follow-up economic census, Indonesia had 26 million micro and small business units. Many people in Indonesia, particularly low-income people, are interested in this sort of micro and small business since it does not have rigorous and complicated regulations, and it does not require special skills [7].

The micro and small business sector arose in Indonesia as a result of the country's low unemployment rate, which prompted people to create small enterprises (Putra, 2016). Furthermore, micro and small enterprises (UMK) can thrive in the context of MSE owners managing their businesses based on their prior work experience [8].

This business sector was able to survive and contribute to the revival of the economy in the midst of a crisis [9].This was demonstrated when micro and small businesses were able to weather the storm of the monetary crisis that hit Indonesia a dozen years ago. small firms that are not dependent on international loans and foreign currencies will not be affected and will be able to survive if a crisis develops that causes the exchange rate to vary [10].

The micro and small business sector is an important part of the Indonesian economy, accounting for up to 90\% of the country's GDP [11] The MSE sector is a business that combines capital, labour, and natural factors to produce goods and services that can be used, and without it, the Indonesian economy would not be able to run. This is because the MSE sector is a business that combines capital, labour, and natural factors to produce goods and services that can be used.

COVID-19 prevention efforts are carried out not only at the headquarters, but also in various regions, one of which is Bali Province. Government of the Bali Province. Gianyar Regency's regional government released Circular Letter of the Regent of Gianyar No: 400/0793/Setda/2020 on the Prevention of Corona Virus Disease (COVID-19) in People's Markets, Supermarkets, and Senggol Markets in Gianyar Regency. This circular regulates the strict adherence to health protocols as well as the imposition of operating hours restrictions at people's markets, senggol markets, supermarkets, and various other types of micro and small businesses that are feared to cause crowds and accelerate the spread of the COVID-19 virus in its implementation. The Gianyar Regent's circular letter undoubtedly has an impact on the income and wellbeing of micro and small business sector actors.
The results received by the company over a period of time are referred to as income [12], [13] Another viewpoint claims that income refers to remuneration received by someone involved in the production process, which can include rent, wages, interest, and profit [14]. In line with this, Suyanto defines income as the amount of money gained by a person as a result of the usage of production elements. Interest for the use of production factors in the form of capital, and profits for the use of production factors in the form of entrepreneurship are all examples of entrepreneurship.

While in the course of business, income can be derived from a variety of sources, including the number of sales of owned goods and services, construction contracts, the use of owned assets, and other income derived from rental and investment activities (Indonesian Institute of Accountants in [15]. Accordingly, operating income can be defined as a collection of incoming assets resulting from the delivery of goods or services to customers [16].

Several factors influence operating income, including product, price, distribution, and promotion [17]Accordingly, the ability of traders, market conditions, capital, business conditions, and other factors all influence the seller's income. The ability of traders to persuade buyers to buy the things they are selling. Market conditions are also essential since they are linked to market circumstances, market type, purchasing frequency, and business location. The capital component has an impact on sales since the bigger the number of items held, the greater the chance for greater earnings. Business conditions are especially crucial since the larger the company, the larger the target market, and thus the higher the profits. The final component, in addition to what has already been mentioned, is the product's promotion and outward appearance [18].

Furthermore, business running hours have a beneficial impact on business players' earnings; the higher the number of working hours, the better the earnings, and vice versa [19], [20].

Meanwhile, the Big Indonesian Dictionary defines welfare as a secure and affluent situation. Family welfare is a state in which all physical, mental, spiritual, and social requirements are addressed, allowing the family to function healthily in the context of the environment (BKKBN, 2002). The level of welfare can be determined by looking at eight areas, according to [21], including poverty, population, health and nutrition, consumption patterns, employment, housing and the environment, education, and other social issues. In line with this, the National Population and Family Planning Agency establishes a number of welfare indicators, including indicators of basic needs or prosperous family indicators I (KS I), indicators of psychological needs or prosperous family indicators II (KS II), indicators of 
development needs or prosperous family indicators III (KS III), and indicators of self-actualization or prosperous family indicators III Plus.

Family members eating twice a day or more, being able to have different clothes for home, school, and work, the house they live in, being able to go to the doctor, being able to go to contraceptive service facilities, and being able to meet the educational needs of children are all examples of basic needs indicators, or KS I indicators. While the KS II indicators or psychological needs include all family members being able to perform religious worship, each family can afford to buy meat, fish, or eggs once a week, can afford to buy a set of clothes once a year, outside the room is eight square meters for each family member, healthy family condition in the previous three months, one or more family members with income, all members aged 10-60 years can read and write, and fertile couples use contraception. The family trying to improve religious abilities, being able to save in the form of money or goods, having the habit of eating together at least once a week, actively participating in activities in the surrounding environment, and families getting information from print media or media on line are all KS III indicators or indicators of development needs. The family that has been able to offer voluntary donations to those in need and has family members who have been involved as administrators of social associations in the community is covered by the prosperous family indicator III plus or self-actualization indicator.

Based on the foregoing expert view, it may be inferred that welfare is a state in which all bodily and spiritual requirements can be met optimally and sustainably, as assessed by a variety of governmentdefined characteristics and criteria.

According to [22] agrees, stating that the level of welfare cannot be isolated from the community's quality of life. As a result, the income per capita of the community is frequently used to measure the level of welfare [23]. This is because household income is seen to be capable of mirroring societal revenue [24]. Another viewpoint claims that the indicators used to assess welfare are based on health, economic status, and education levels [25]. Individual security, social freedom, state of governance, social capital ownership, economic conditions, health conditions, infrastructure, level of investment, market conditions, quality of life, and natural environment are all characteristics that can be used to assess welfare [26].

\section{METHOD}

This is descriptive study that employs a quantitative approach. The purpose of descriptive research is to describe the impact of Gianyar Regent Circular No:
400/0793/Setda/2020 addressing the procedures for preventing COVID-19 transmission in Gianyar Regency. This study took place in all of Gianyar Regency's sub-districts, specifically in Ubud District, Gianyar District, Sukawati District, Blahbatuh District, Tampaksiring District, Tegallalang District, and Payangan District.

The participants in this study were all micro and small business owners who worked in Gianyar Regency's numerous people's markets, senggol markets, supermarkets, and klontong stalls. In this study, 381 samples were collected and divided throughout all districts. A cluster random sampling technique was used, with each sub-district receiving a distinct number of samples. With a sample size of 16.54 percent, Gianyar District was chosen. Ubud District has a population of 19.98 percent, Sukawati District has a population of 22.05 percent, Blahbatuh District has a population of 17.06 percent, Payangan District has a population of 6.56 percent, Tampaksiring District has a population of 9.45 percent, and Tegallalang District has a population of 8.66 percent. The number of UMK participants in each sub-district is used to alter the sampling.

The findings of this study were obtained in textual form, as well as numbers, which were examined, presented, described, and fitted to reality before being utilized to draw conclusions. Primary data in the form of questionnaires and interview results were used in this study so that responses could be gathered directly from each respondent, and secondary data in the form of data on the number of MSEs from BPS Kab. Gianyar. Questionnaires and interviews were used to collect data for this study. This questionnaire was created using a four-point Likert scale, ranging from 1 to 4 , with 1 indicating strong disagreement and 4 indicating strong agreement. The validity and reliability of the instrument to be employed were assessed before to data collection using the SPSS 20.0 for Windows application. If the alpha error level is 0.05 , the questionnaire instrument is deemed to be valid. Meanwhile, if a variable has a cronbanch'c alpha value $>$ of 0.60 , it is deemed to be reliable.

The descriptive analytic technique was utilized in this study to describe the influence of the Gianayr Regent Circular No: 400/0793/Setda/2020 on the income and welfare levels of MSEs in Gianyar Regency. According to Irianto (2004), the procedures in the descriptive analysis are to determine the lowest and highest score from all alternative responses. The formula for calculating the highest and lowest scores, namely the highest score, is determined by multiplying the highest score by the number of questions and respondents. To find the lowest score, reverse the process. Where four is the highest value and one is the lowest. Then, using the formula for the greatest score 
minus the lowest score divided by the category, calculate the interval.

\section{RESULTS \& DISCUSSION}

\subsection{Research Result}

Based on the results of data collection, the MSE income score in Gianyar Regency is 3,977. Furthermore, the score is categorized based on the range of scores in the Table 1.

Table 1. Income variable score range

\begin{tabular}{|c|c|c|}
\hline No. & Interval & Category \\
\hline 1 & $4.940-6.080$ & Strongly Agree \\
\hline 2 & $3.799-4.939$ & Agree \\
\hline 3 & $2.658-3.798$ & Disagree \\
\hline 4 & $1.517-2.657$ & Strongly Disagree \\
\hline
\end{tabular}

By looking at the reference in table 1, the numbers are in the score range of 3,799-4,939 with the agree category, so in other words, the community of MSE actors agrees that the implementation of the Gianyar Regent Circular No: 400/0793/Setda/2020 has an effect on decreasing people's income.

Meanwhile, the UMK welfare score in Gianyar Regency is 15,244. Furthermore, the score is categorized based on the range of scores in Table 2.

Table 2. Gianyar regency MSEs welfare score

\begin{tabular}{|c|c|c|}
\hline No. & Interval & Category \\
\hline 1 & $18.075-22.800$ & Strongly Agree \\
\hline 2 & $13.799-18.074$ & Agree \\
\hline 3 & $9.523-13.798$ & Disagree \\
\hline 4 & $5.248-9.522$ & Strongly Disagree \\
\hline
\end{tabular}

In accordance with the reference table 2, the numbers are included in the score range of 13,79918,074 in the agree category. So, in other words, UMK actors in Gianyar Regency agree that the Gianyar Regent's Circular has an effect on decreasing the welfare of UMK actors in Gianyar Regency.

\subsection{Discussion}

The implementation of the Gianyar Regent's circular letter No: 400/0793/Setda/2020, which regulates the procedures for controlling the spread of COVID-19 and includes regulations for limiting business operating hours, has an impact on the income and welfare of MSE Gianyar Regency.

MSE businessmen claimed that their businesses had dropped by up to $50 \%$. According to Ni Wayan Tagel, one of the traders at the Tampaksiring Market, the implementation of this regulation resulted in the shortening of business opening hours. According to his narrative, the implementation of shorter operating hours resulted in a significant decrease in income, as well as many people who did not dare to conduct cash transactions for fear of the COVID-19 virus spreading. Another opinion expressed on behalf of Putu Suasni, one of the traders at the Senggol Sayan market, stated that the number of consumers has decreased dramatically since the enactment of the circular letter, owing to a reduction in business hours to five hours, even though he assumes that if the business hours are extended, the opportunities to generate income will increase. In addition to the reduced operating hours, he added that this was due to people's fear of getting the COVID-19 virus if they ate food from outside.

This study supports Suprapti (2017)'s findings on the impact of education, working hours, age, and capital on the income of female traders in the Bantul Barongan market. The income of market traders in Bantul is positively impacted by the changing working hours. Furthermore, other similar studies show the same conclusion, such as Dewi, P., (2012) research, which claims that the longer traders open their kiosks, the greater the chance of generating bigger money.

The outcomes of this investigation show a decline in MSE actors' welfare. This level of welfare is expressed in numerous indicators, including basic requirements such as clothing, food, and shelter, communication, educational, and health indicators. Ni Putu Ayu, a trader in Gianyar's Senggol market, claimed that since the COVID-19 outbreak he has limited back on buying ready-made food, clothes, and even electronic devices. Mr. Roni agreed, stating that his micro-businesses had not developed since the COVID-19 Pandemic and had deteriorated after the circular letter's enactment. Mr. Sutedja explained that MSE actors reduce their children's participation in non-formal educational institutions, such as courses that were formerly routinely followed. Adjustments are made in the education sector as well as communication spending such as internet packages and other electronic gadgets. Due to the absence of public interest in performing transactions in MSEs, micro business operators adapt or lower the volume of merchandise.

Widiana \& Wenagama (2019) found that increasing income promotes welfare, and vice versa. To support this viewpoint, Purbawati et al. (2020) stated that social distancing policies reduced people's purchasing power, affecting the welfare of traders at the Kertasura Market, causing micro business actors to take various actions. UMK actors' efforts tend to reduce the amount of merchandise they have, while also looking for new business prospects to aid the family economy and small business actors in handicrafts, fast food, and clothes. Moreover, these findings are in line with Widyastuti's (2012) research, which demonstrates that productivity has a major impact on income, and vice versa. In this 
situation, the more productive an individual is, the If many business operating hours are used, the opportunity to earn income will increase if the business operating hours are reduced and the productivity level is also reduced, it will cause a decrease in income so that it will cause the need for welfare to be less fulfilled.

\section{CONCLUSION}

\subsection{Conclusion}

Based on the aforementioned data, it can be inferred that the implementation of the Gianyar Regent's Circular No: 400/0793/Setda/2020 has an impact on MSE income. Merchants claim that the drop in income is due to a decrease in people's purchasing power as a result of the COVID pandemic.

Furthermore, the implementation of the Gianyar Regent's Circular No: 400/0793/Setda/2020 has an influence on the welfare of MSEs, because the COVID19 outbreak and the reduction in business hours have resulted in poor demand for items offered. As a result, MSE actors must make adjustments to their item purchases as well as their other demands, such as basic needs, communication, education, and health.

\subsection{Suggestion}

According to the findings of the research, discussion, and conclusions described above, the researchers' recommendations to the local government of Gianyar Regency are to re-evaluate the circular letter that has been determined; this recommendation is based on the opinion of those who have experienced a decrease in income since the circular's implementation.

As for other researchers, it is encouraged to expand on this research, as this study focused exclusively on the subject of a regulation and the MSE, allowing for additional development, such as comparing the income and welfare of MSEs in one area to those in other locations.

\section{REFERENCES}

[1] D. Telaumbanua, "Urgensi Pembentukan Aturan Terkait Pencegahan Covid-19 di Indonesia," QALAMUNA J. Pendidikan, Sos. dan Agama, vol. 12(01), pp. 59-70, 2020, doi: 10.37680/qalamuna.v12i01.290.

[2] A. F. Thaha, "Dampak Covid-19 Terhadap UMKM di Indonesia," J. Brand, vol. 2(1), pp. 147-153, 2020.

[3] A. Kresna and J. Ahyar, "Pengaruh Physical dan Social Distancing Terhadap Kesehatan Dalam Pendekatan Linguistik," vol. 1(1), pp. 14-19, 2020.
[4] Lembaga Ilmu Pengetahuan Indonesia, "Diagnosis Ekonomi Nasional Terhadap Kinerja UMKM di Pandemi COVID-19," Lembaga Ilmu Pengetahuan Indonesia, 2020. .

[5] Badan Pusat Statistic, "Pertumbuhan Ekonomi Indonesia Triwulan IV-2019," Www.Bps.Go.Id, no. 17/02/Th. XXIV, 2020. .

[6] W. laura Hardilawati, "Strategi Bertahan UMKM di Tengah Pandemi Covid-19," J. Akunt. dan Ekon, vol. 10(1), pp. 89-98, 2020, doi: 10.37859/jae.v10i1.1934.

[7] A. Primatami and N. Hidayati, "Perkembangan Usaha Mikro Kecil (Umk) Di Provinsi Jawa Barat Tahun 2006 - 2016," J. Pengemb. Wiraswasta, vol. 21(3), p. 203, 2019, doi: 10.33370/jpw.v21i3.350.

[8] E. L. Eijdenberg, "Exploring Sustainability Orientation of MSME-Owners in Tanzania," $J$. Enterprising Cult, vol. 27(01), pp. 35-59, 2019, doi: $10.1142 / \mathrm{s} 021849581950002 \mathrm{x}$.

[9] N. G. A. N. A. Utari and M. K. S. Budhi, "The Influences Of Regional Credit Guarantee (Jamkrida), Working Capital, And Government's Role On Micro, Small And Medium Enterprises (MSMEs) Welfare In Denpasar City," Russ. J. Agric. Socio-Economic Sci, vol. 91(7), pp. 148-155, 2019, doi: 10.18551/rjoas.2019-07.15.

[10] Bank Indonesia dan LPPI, "Profil Bisnis Usaha Mikro, Kecil dan Menengah (UMKM)," Bank Indones dan LPPI, 2015. .

[11] I. A. C. S. Mandasari and I. G. S. Pratama, "Use of e-commerce during COVID-19 pandemic towards revenue and volume of MSMEs sales," Int. Res. J. Manag. IT Soc. Sci, vol. 7(6), pp. 124-130, 2020, doi: 10.21744/irjmis.v7n6.1022.

[12] Reksoprayitno, Sistem Ekonomi Dan Demokrasi Ekonomi. Jakarta: Bina Grafika, 2004.

[13] H. D. S, Pengantar Akuntansi I (Teori \& Praktik). Madiun: Aditya Media Publishing, 2016.

[14] Y. Sudremi, Pengantar Sosial Ekonomi SMA/MA 2 Kelas XI. Jakarta: Bumi Aksara, 2007.

[15] R. O. Kawantu, V. Ilat, and A. Wangkar, "Analisis Pengakuan Pendapatan Dan Beban Berdasarkan Standar Akuntansi Keuangan Entitas Tanpa Akuntabilitas Publik (Sak Etap) Pada Koperasi Pegawai Republik Indonesia (Kpri) Dinas Pendidikan Daerah Provinsi Sulawesi Utara," J. EMBA J. Ris. Ekon. Manajemen, Bisnis dan Akunt, vol. 7(3), pp. 3528-3537, 2019, doi: 10.35794/emba.v7i3.24648. 
[16] Soemarso, Akuntasi Suatu Pengantar. Jakarta: Salemba Empat, 2009.

[17] J. Wilkinson, Sistem Akuntansi dan Informasi: Edisi Ketiga. Jilid Satu. Alih Bahasa Agus Maulana. Jakarta, 2010.

[18] Mulyadi, Sistem Akuntansi Edisi Ketiga. Jakarta: Selemba Empat, 2010.

[19] M. Imron and P. A. Wibowo, "Analisis FaktorFaktor Yang Mempengaruhi Tingkat Keberhasilan Usaha (Studi Pada Warung 'Nasi Kucing' Di Kabupaten Jepara)," J. Din. Ekon. Bisnis, vol. 5(2), pp. 111-132, 2008.

[20] N. Nursyamsu, I. Irfan, I. R. Mangge, and M. A. Zainuddin, "Pengaruh Modal Kerja dan Jam Kerja Terhadap Pendapatan Pedagang Kaki Lima di Kelurahan Kabonena," J. Ilmu Ekon dan Bisnis Islam, vol. 2(1), pp. 90-105, 2020, doi: 10.24239/jiebi.v2i1.25.90-105.

[21] Badan Pusat Statistika, "Ekonomi Indonesia Triwulan II 2019 Tumbuh 5,05 Persen," bps.co.id, 2019. .

[22] W. A, “Analisis Hubungan Antara Produktivitas Pekerja Dan Tingkat Pendidikan Pekerja Terhadap Kesejahteraan Keluarga Di Jawa Tengah Tahun 2009," Econ. Dev. Anal. J, vol. 1(2), 2012, doi: 10.15294/edaj.v1i2.472.

[23] A. L, Ekonomi Pembangunan. Yogyakarta: UPP STIM YKPN, 2010.

[24] Bappenas, "Penyelenggaraan Pemerintah dan Pembangunan Daerah,” vol. 53(9), 2007.

[25] P. R. Arini, "Pengaruh Belanja Modal Terhadap Pertumbuhan Ekonomi Dan Kesejahteraan Masyarakat Di Pulau Kalimantan," JRAMB, vol. 2(2), pp. 180-198, 2016.

[26] A. Khorram-Manesh, E. Carlström, A. J. Hertelendy, K. Goniewicz, C. B. Casady, and F. M. Burkle, "Does the prosperity of a country play a role in COVID-19 outcomes?," Disaster Med. Public Health Prep, 2020. 